EESTI NSV TEADUSTE AKADEEMIA TOIMETISED, 26. KOIDE KEEMIA * GEOLOOGIA. 1977, Nr. 1

НЗВЕСТИЯ АКАДЕМИИ НАУК ЭСТОНСКОИ ССР. ТОМ 26 ХИМИЯ * ГЕОЛОГИЯ. 1977, № 1

\title{
НОВЫЕ ЭНКРИНУРИДЫ (TRILOBITA) ЛЛАНДОВЕРИ ПРИБАЛТИКИ
}

Среди раннесилурийских трилобитов Прибалтики энкринуриды наиболее богатое по видовому составу семейство. Они сравнительно хорошо изучены по материалам, собранным из обнажений Эстонии (Schmidt, 1881; Rosenstein, 1941; Мянниль Р. М., 1958; Мянниль Р. П., 1968). Относительно глубоководные отложения силура Прибалтики, вскрытые буровыми скважинами в южной части Эстонии, в Латвии и Литве, содержат в основном неизвестные в полосе выходов виды. Из них в данной статье описываются четыре новые формы, происходящие из юуруского, райккюлаского и адавереского горизонтов.

Наряду с общепринятой терминологией (Чернышева, 1960; Moore, 1959) здесь используются некоторые специальные выражения, предложенные для энкринурид Дж. Темпле (Temple, 1956) и Р. Триппом (Tripp, 1957). Сюда относятся: ложная предглабельная борозда, псевдоглабельное поле неподвижных щек и ложное предглабельное поле. Бугорки глабели индексированы по системе Р. Триппа (Tripp, 1957, 1962). Размеры изученных экземпляров приведены в таблице. При выполнении фотоснимков пользовались кругообразной лампой. Предварительно экземпляры покрывались хлористым аммонием. Описанный материал хранится в Институте геологии АН ЭССР в Таллине.

Большинство лландоверийских энкринурид Прибалтики, в том числе и три новых нижне- и среднелландоверийских вида, близки к видам E. shelvensis и E. mullochensis из верхнего валентиана Англии (Whit$\operatorname{tard}, 1938)$. Характерным для них являются отсутствие щечных и хвостовых шипов и умеренное количество рахиальных колец пигидия. Морфологически они родственны с представителями рода Fragiscutum (Whittington, Campbell, 1967), несходство касается лишь количества плевральных сегментов торакса. В дальнейшем их, по-видимому, целесообразно рассматривать в составе единого рода или подрода. Кстати, Э. Шранк (Schrank, 1972) считает возможным присоединить Fragiscutum к группе E. variolaris (по классификации Reed, 1928), хотя представители последней с их длинными(саг.) рахиальными кольцами пигидия, количество которых едва превышает количество плевральных ребер, заметно отличаются от видов рода Fragiscutum (и видов, близких к E. shelvensis).

Из нижеописанных видов наиболее молодой позднелландоверийский вид E. triangulus разнится от остальных наличием хвостовых шипов и более четкой туберкуляцией глабели, т. е. признаками, свойственными уже группе E. punctatus. 


\section{Encrinurus rotundus sp. n.}

Табл. I, фиг. $1-2$; рис. 1

Г олотип. Спинной щит с гипостомой, $\operatorname{Tr} 2504$. Скв. Лаэва, гл. 121,2 м. Юуруский горизонт, нижний лландовери.

Матери ал. Голотип и 5 пигидиев.

Ди агноз. Глабель выпуклая, несет около 70 бугорков. На ложном предглабельном поле 12 небольших бугорков. Щечные углы без шипов. Гипостома с широкой передней каймой, свободной от срединного тела. Пигидий с округлым концом. Ширина пигидия больше его длины. Спинные борозды дугообразно загнуты. Рахис широкий $(0,4$ ширины пигидия), состоит из 15 колец. Пострахиальный валик доходит до края пигидия.

О пис ание. Выпуклый головной щит с округлым передним краем. Глабель выпуклая, отношение длины к ширине 1,1 .

Базальные лопасти глабели низкие, удлиненные (тр.), без бугорков. Остальные боковые лопасти покрыты крупными, удлиненными к спинным бороздам бугорками и отделены друг от друга короткими неглубокими бороздами. Предглабельная борозда выражена более четко по бокам глабели и довольно слабо в осевой части (табл. I, фиг. 1, в).

Спинные борозды глубокие и широкие, дугообразно расходящиеся. Затылочное кольцо выпуклое, немного перекрывающее (тр.) базальную часть глабели. Щеки, и особенно задневнутренние их части, выпуклые, значительно выступающие над задней краевой каймой. Щечные углы прямоугольные. Подвижные щеки направлены почти вертикально вниз. Боковая борозда умеренно глубокая и широкая, боковая кайма широкая, дугообразно расширяющаяся перед щечным углом.

Передние ветви лицевых швов соединяются под тупым углом. Глаза относительно маленькие, конические, к основанию сужены. Рострум из-за небольшой вдавленности передней части головного щита голотипа частично скрыт, он имеет, по-видимому, форму удлиненного киля.

Гипостома ромбическая, передний конец тупой, задний остроугольнозакругленный. Срединное тело овальное, сильно выпуклое. Его передний склон крутой, слегка нависающий над передней бороздой. Передняя лопасть срединного тела ограничена двумя, косо расположенными по бокам удлиненными углублениями. Макулы выражены вблизи заднебоковой борозды в виде овальных возвышений. Передняя краевая кайма узкая, повернута вниз, отделена от срединного тела широкой передней бороздой. Боковая кайма более плоская и широкая, боковая борозда узкая. Задняя кайма образует с округленным концом остроугольный язык, который составляет около одной четверти длины всей гипостомы.

Скульптура выражена четко по всему головному щиту. На глабели около 70 бугорков, из них нанболее крупные (диаметром около 1 мм) расположены на боковых лопастях. Размер остальных бугорков уменьшается в основном сзади вперед. Расположение бугорков в задней части глабели по системе Р. Триппа (Тripp, 1957) следующее: I-1; ii-0; II-1,2; iii-0 (рис. 1). В передней части глабели бугорки расположены более хаотично. Ложное предглабельное поле несет 12 бугорков, из них крайние крупные (диаметром около 1 мм), а остальные (диаметром 0,3-0,6 мм. по величине аналогичны бугоркам на фронтальной лопасти глабели. На псевдоглабельном поле около 50 таких же по размерам бугорков. На щечном поле два наиболее крупных и вытянутых к спинным бороздам бугорка находятся между глазом и спинной бороздой, а наиболее мелкие на заднебоковой части неподвижной щеки. От основания глаза 

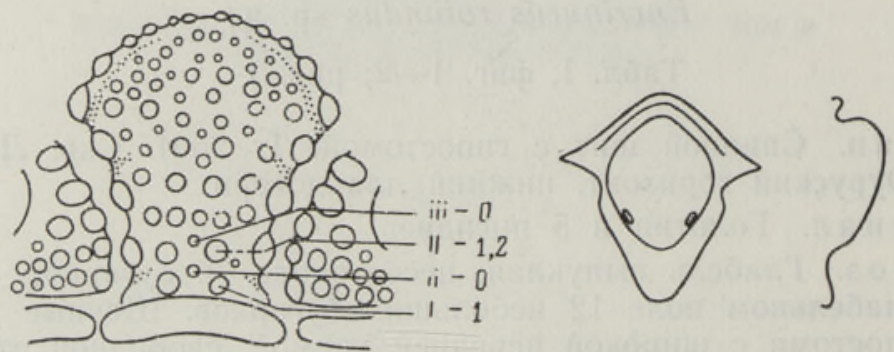

Рис. 1. Расположение бугорков на глабели и строение гипостомы Encrinurus rotundus sp. п. Нндексация бугорков по системе Р. Триппа (Tripp, 1957).

бугорки несколько удалены. На передней и задней каймах есть ряд нечетких бугорков. По внутреннему краю боковой каймы просматривается ряд довольно четких бугорков (диаметром около $0,5 \mu м$ ), а на остальной части несколько мелких и бессистемно расположенных.

На верхушке бугорка глабели обычно находится пора. Поверхность бугорков зернистая, причем зернистость между бугорками глабели почти или совсем отсутствует, а на передней и боковых краевых каймах и дублюре, а также на гипостоме развита относительно хорошо.

Туловище состоит из 11 сегментов. Рахис широкий, шире плеврального поля. Спинные борозды по ширине и глубине умеренные. На проксимальных частях плевр и кольцах рахиса выделяются слаборазвитые бугорки с порами.

Пигидий с округлым задним концом. Отношение ширины пигидия к его длине около 1,2. Рахис широкий, составляет 0,4 ширины пигидия. На рахисе 15 колец. После второго кольца в осевой части рахиса борозды выражены слабо - налицо почти гладкий осевой пояс. Спинные борозды умеренно низкие, дугообразно выгнутые. Плевральное поле несет 7 ребер, разделенных широкими межплевральными бороздами. Между слабо загнутыми седьмыми ребрами проходит пострахиальный валик от рахиса до заднего края пигидия. Он, по-видимому, образован слиянием двух последних ребер; иногда в передней части валика имеется удлиненное углубление. Дублюра довольно широкая, расположена косо вниз. Скульптура пигидня образована в основном осевыми бугорками на кольцах рахиса, которые начинаются от третьего или четвертого кольца и повторяются через каждые три. На передних двух кольцах ряд небольших бугорков. Плевральные ребра почти без бугорков. Поверхность колец рахиса, плевральных ребер и дублюры зернистая.

С равнение. $E$. rotundus с широким, округло-треугольным пигидием близок к верхнелландоверийскому виду E. palmrei (Мянниль Р. М., 1958); отличается от последнего почти прямыми седьмыми плевральными

Фнг. 1-2. Encrinurus rotundus sp. n. 1 - голотип, полный спинной щит, $\operatorname{Tr} 2504$, скв. Лаэва, гл. $121,2 м, \mathrm{G}_{1-2}: 1, a-$ общий вид, $\times 3 ; 1,6$ - вид сбоку, $\times 3 ; 1$, в - вид спереди, $\times 4 ; 1,2-$ вид снизу на головной щит с гипостомой, $\times 3 ; 2-$ пигидий, $\operatorname{Tr} 1973$, $\times 4$, скв. Сурвакюла, гл. 190,5 м: 2, a - общий вид; 2, б - вид сзади, 2, в - вид сбоку. Фиг. 3-4. Encrinurus cf. kiltsiensis Rosenstein. 3 - головной щит, $\operatorname{Tr} 2755 \mathrm{a}, \times 3$, скв. Пярну, гл. 221,3 м, $\mathrm{G}_{1-2} ; 4$ - пигидий, $\operatorname{Tr} 2754, \times 3,7$, скв. Пярну, гл. 221,3 м.

Фиг. 5-10. Encrinurus abyssalis sp. n. 5 - подвижная щека, $\operatorname{Tr} 1983$ d, $\times 3,5$, скв. Колка, гл. 604,3 м; 6 - голотип, неполный кранидий, $\operatorname{Tr} 1982, \times 4$, скв. Колка, гл. 604,1 м, $\mathrm{G}_{3} ; 7$ - пигидий, $\operatorname{Tr} 1984, \times 4$, скв. Колка, гл. 602,6 м; 8 - кранидий, $\operatorname{Tr} 1983 \mathrm{a}, \times 4$, скв. Колка, гл. 604,3 м; 9 - гипостома, $\operatorname{Tr} 1983 \mathrm{~b}, \times 4$, там же; 10 - пигидий, $\operatorname{Tr} 1983 \mathrm{c}$, $\times 4$, там же. 
ТАБЛИЦА I

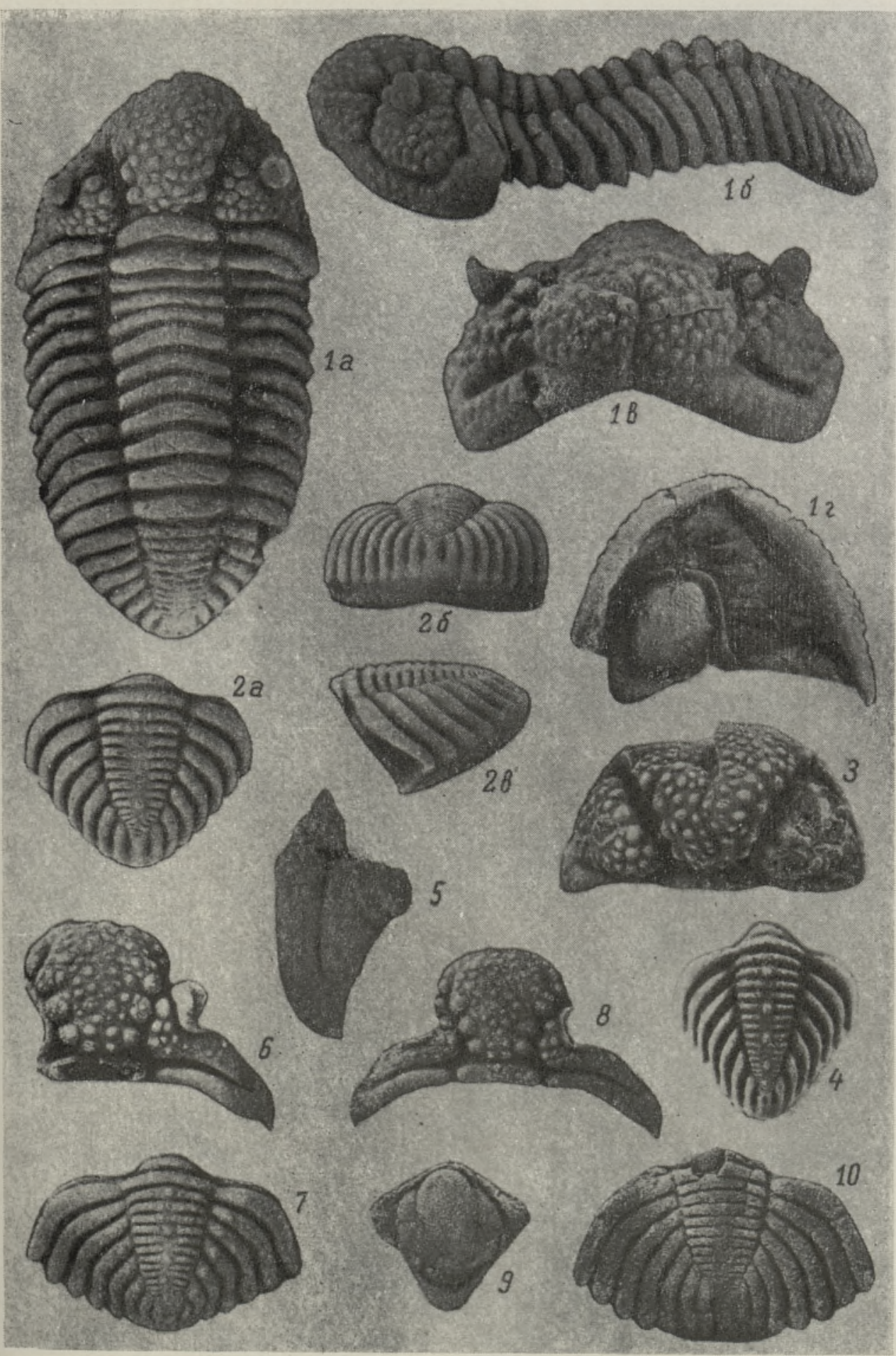




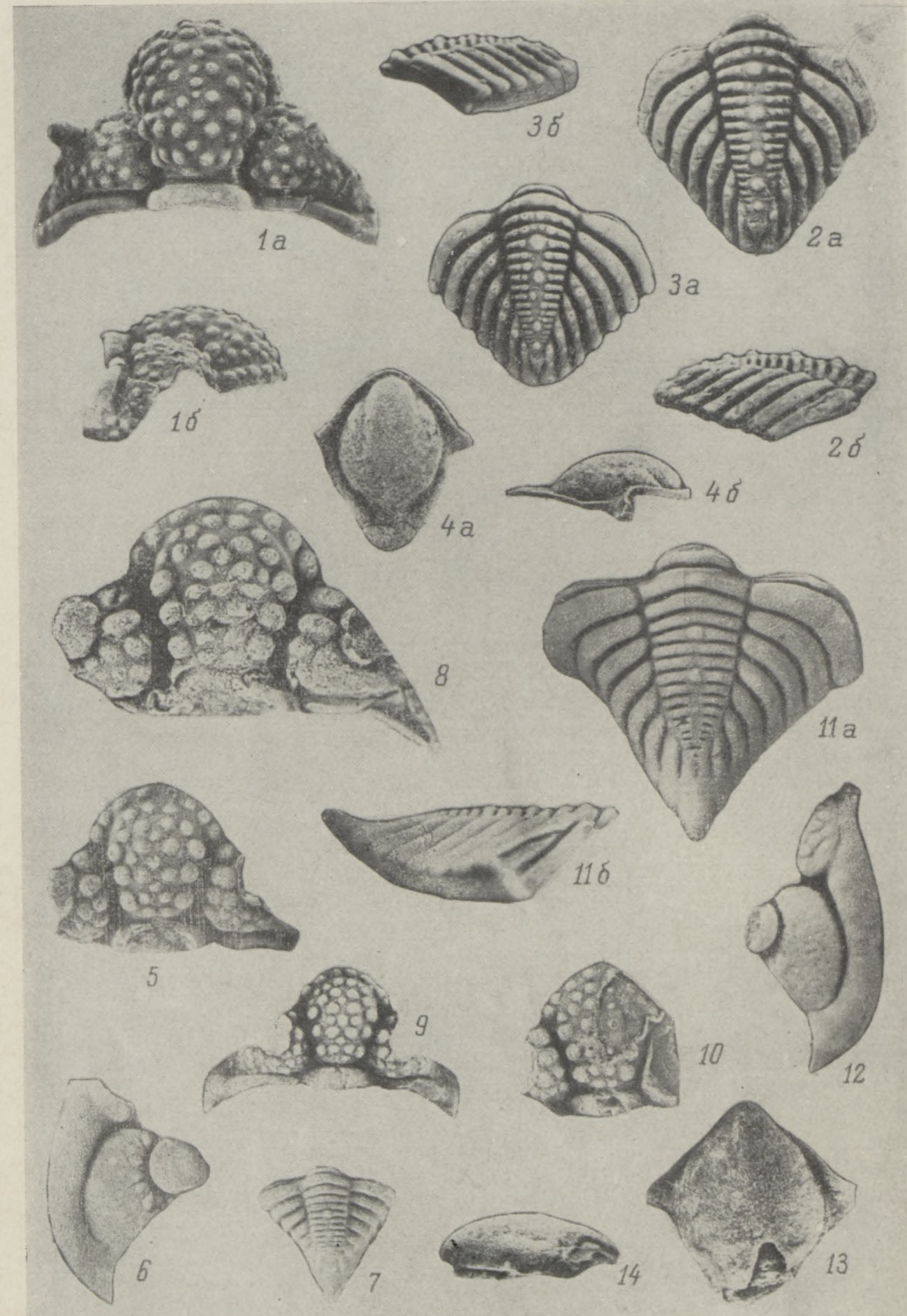


ребрами пигидия (у E. palmrei они загнуты, а потому пострахиальный валик не достигает края пигидия), более коротким рахисом и иным расположением осевых бугорков.

Головной щит изученного вида напоминает таковой у E. cf. kiltsiensis (табл. I, фиг. 3-4). Основное отличие - менее выпуклое щечное поле, меньшее количество бугорков на нем и на псевдоглабельном поле. Хвостовые щиты обоих видов отличаются значительно.

Р а с п р ост р а н е н и е. Скв. Лаэва, $121,2-125,5 \mu ;$ скв. Сурвакюла, гл. 190,5 м; скв. Отепя, гл. 120,7 м; скв. Хяэдемээсте, гл. 408,8 м. Нижний лландовери, юуруский горизонт.

\section{Encrinurus selistensis sp. $\mathrm{n}$.}

Табл. ІІ, фиг. $1-4 ;$ рис. 2

Г ол о ти п. Кранидий и пигидий, Тr 2750 a, b. Скв. Селисте, гл. 283,4 м. Райккюлаский горизонт, средний лландовери.

$M$ а те ри ал. Голотип, 1 кранидий, 2 гипостомы, 5 пигидиев.

Д и а г н з. Умеренно выпуклая глабель несет 54 бугорка. На ложном предглабельном поле 12 , на пальпебральном поле 5-6 бугорков. Щечные углы без шипов. Передняя лопасть срединного тела гипостомы слегка нависает над передней бороздой, но не покрывает передний край. Пигидий треугольный с закругленным концом; ширина пигидия немного превышает его длину. Спинные борозды слегка выгнуты. Рахис состоит из $20-22$ колец, плевральное поле из 7 ребер. Пострахиальный валик не доходит до края пигидия.

О писание. Глабель умеренно выпуклая, отношение ее длины к ширине 1,1. Базальные лопасти развиты в виде низких плоских валиков, а остальные боковые лопасти - в виде относительно крупных округлых бугорков, между которыми проходят едва заметные боковые борозды. Предглабельная борозда выражена только по бокам глабели. Спинные борозды глубокие, умеренно широкие, полого вогнутые.

Щеки умеренно выпуклые. Щечные углы приблизительно прямоугольные. Передние ветви лицевых швов соединяются перед кранидием почти по прямой линии. Задние ветви после небольшого поворота недалеко от глаза проходят почти прямо до бокового края. Глаза несколько удалены от спинных борозд.

Гипостома ромбическая, с закругленно-остроугольными передним и задним концами. Срединное тело овальное, его передняя лопасть ограничена прямыми, почти параллельными бороздами. Макулы расположены вблизи заднебоковой борозды в виде овальных возвышений. Передняя часть передней лопасти нависает над передней краевой бороздой, не покрывая кайму. Передние борозда и кайма относительно узкие, кайма

Фиг. 1-4. Encrinurus selistensis sp. n. 1,2 - голотип, $\operatorname{Tr} 2750$ a, b, X 3 ; скв. Селисте, гл. 283,4 м, $\mathrm{G}_{3}: 1, a-$-бщий вид кранидия, 1, б- вид сбоку, $2, a-$ общий вид пигидия, 2,6 - вид сбоку; 3 - пигидий, $\operatorname{Tr} 2751, \times 3,8$, скв. Селисте, гл. 284,1 м: $3, a-$ общий вид, 3,6 - вид сбоку; 4 - гипостома, $\operatorname{Tr} 2752, \times 5$, скв. Селисте, гл. 282,6 : $4, a$ - общий вид, 4,6 - вид сбоку.

5-14. Encrinurus triangulus sp. п. 5 - голотип, неполный кранидий, $\operatorname{Tr} 1976 a, \times 4$, скв. Oxесааре, гл. 350,0 м, Н; 6 - подвижная щека, $\operatorname{Tr} 1976 \mathrm{~b}, \times 4$, там же; 7 - пигидий, $\operatorname{Tr} 1976 \mathrm{c}, \times 4$, там же; 8 - неполный кранидий, $\operatorname{Tr} 2075, \times 4$, скв. Охесааре, гл. 351,7 ; 9 - кранидий, $\operatorname{Tr} 2766 a, \times 4$, скв. Каугатума, гл. 250,2 м; 10 - неполный кранидий, Tr 1977, × 4, скв. Охесааре, гл. 351,5 м; 11 - пигидий, Tr 1980a, × 4, скв. Колка, гл. 571,5 м: 11, a - общий вид, 11,6 - вид сбоку; 12 - подвнжная щека, $\operatorname{Tr} 1980 \mathrm{~b}, \times 3$, там же; 13 -гипостома, $\operatorname{Tr} 2766 \mathrm{~b} \times 4$, скв. Каугатума, гл. 250,2 м; 14 - гипостома, внд сбоку, $\operatorname{Tr} 2761, \times 4$, скв. Рухну, гл. 458,4 $м$.

4 ENSV TA Toimetised $\mathrm{K} * \mathrm{G}-11977$ 


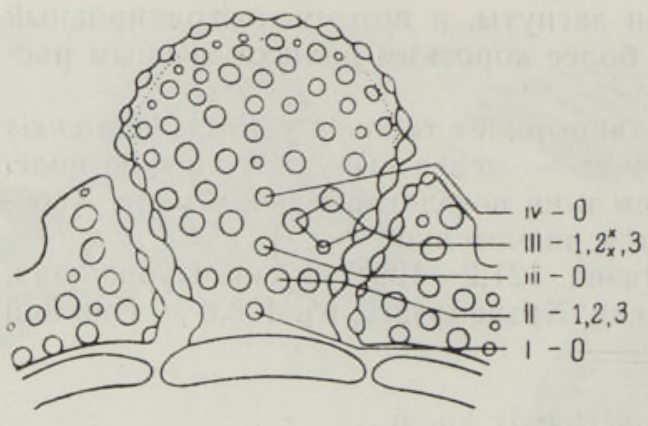

Рис. 2. Расположение бугорков на глабели Encrinurus selistensis sp. $\mathrm{n}$.

повернута вниз. Задняя кайма образует с округлым концом язык, длина которого составляет 0,22 длины всей гипостомы.

Скульптура на кранидии образована четкой, относительно однородной бугорчатостью. На глабели 54 бугорка диаметром до 1 мм. Из них бугорки на боковых лопастях лишь немного больше остальных. Расположение бугорков на задней части глабели по системе Р. Триппа следующее: $\mathrm{I}-0 ; \mathrm{II}-1,2,3$; iii-0; III- $1,2_{*}^{*}, 3$; iv-0 (рис.

2). Перед второй лопастью бугорки расположены хаотично. Ложное предглабельное поле несет 12 бугорков по размерам одинаковых с бугорками на фронтальной лопасти глабели. Бугорки неподвижной щеки немного меньше находящихся на глабели, особенно меньше ряд бугорков, расположенных по краю спинной борозды. Пальпебральное поле покрыто 5-6 бугорками. На затылочном кольце и задней краевой кайме бугорки низкие и нечеткие. Все бугорки кранидия покрыты порами, количество которых колеблется от одной (на щеках и каймах) до трех (на передней части глабели). Поверхность бугорков, затылочного кольца, задней каймы и гипостомы зернистая.

Подвижные щеки и туловище не найдены.

Пигидий треугольного очертания с округлым концом. Ширина пигидия немного (в 1,1-1,2 раза) больше его длины. Спинные борозды слегка выгнутые, умеренно глубокие. Рахис равномерно суживается к концу, его ширина составляет 0,35-0,40 ширины пигидия. На рахисе выделяется 20-22 кольца. За третьим кольцом проходит узкий осевой пояс. Плевральное поле имеет 7 ребер, повернутых относительно круто назад. Последние ребра, сближаясь, образуют округленный конец пигидия. Килевидный пострахиальный валик между ними не достигает края пигидия.

Скульптура пигидия выражена четко. Осевые бугорки (диаметром 0,7 мм) начинаются от третьего или четвертого кольца и повторяются через каждые 3-4. Кроме того, довольно четко прослеживаются второстепенные бугорки вдоль передних колец и по бокам остальных. Из последних проксимальные бугорки ясно маркируют осевой пояс рахиса. На плевральных ребрах также есть ряд бугорков. Количество пор на осевых бугорках 2-4, на остальных по 1.

С равнение. Описанный вид близок к нижнелландоверийскому виду E. kiltsiensis (Rosenstein, 1941; Мянниль, 1958), особенно по строению хвостового щита (сохранность последнего, к сожалению, оставляет желать лучшего). Пигидий E. selistensis отличается от E. kiltsiensis, по-видимому, слабо выгнутыми спинными бороздами, относительно короткой последней парой плевральных ребер и четкой сплошной бугорчатостью. Его кранидий отличается относительно равномерными по величине бугорками на глабели и задневнутренней части неподвижных щек, а также расположением бугорков на базальной части глабели.

От E. shelvensis (Whittard, 1938) наш вид отличается прежде всего бо́льшим количеством бугорков на ложном предглабельном поле (у вида из Англии их 8) и меньшим количеством плевральных ребер пигидия. 
Р а сп р ост р ан ен и е. Скв. Селисте, 282,6-284,1 $м$; скв. Сурвакюла, 150,6 м; скв. Ристикюла, 233,4 м. Средний лландовери, райккюлаский горизонт.

\section{Encrinurus abyssalis sp. $\mathrm{n}$.}

табл. I, фиг. $5-10$; рис. 3

Г олотип. Кранидий, Тr 1982. Скв. Колка, гл. 604,1 м. Райккюлаский горизонт, средний лландовери.

$M$ а тер и ал. 4 кранидия, 2 подвижные щеки, 1 гипостома, 6 пигидиев. Материал частично вдавлен.

Д и а г о з. Кранидий плоско-выпуклый, с полого выгнутым передним краем. На глабели около 50 бугорков, на ложном предглабельном поле 10-12 мелких бугорков. Глазные крышки длинные, передние их концы приближаются к глабели. Пигидий широкий, с закругленным концом. Рахис имеет 15-16 колец, плевральное поле 8 пар ребер, из которых последняя находится в зачаточном виде и не достигает края пигидия.

О пи с ание. Трилобит небольших размеров. Кранидий широкий (отношение ширины к длине 2,5), с полого выгнутым передним краем. Глабель слабо выпуклая. Базальные лопасти выражены очень слабо. Боковые лопасти покрыты крупными бугорками, между которыми пролегают короткие борозды. Предглабельная борозда довольно четко видна по бокам глабели и едва заметна в средней своей части. Узкие спинные борозды слабо вогнуты.

Щеки широкие; щечные углы кончаются короткими шипами длиной до 0,5 мм. Подвижная щека имеет относительно узкую боковую борозду и широкую кайму.

Передние ветви лицевых швов соединяются почти по прямой линии. Задние ветви проходят плавными загибами от глаз до боковых краев. Глазные крышки длинные (саг.), передние их концы приближаются к спинным бороздам.

Гипостома вдавлена. Она имеет закругленные передний и задний концы. Передняя лопасть срединного тела выражена четко, над передней краевой бороздой не нависает. Передние кайма и борозда узкие. Задняя кайма образует короткий язык, длина которого составляет около 0,2 длины всей гипостомы.

Скульптура на глабели образована разными по величине бугорками. Относительно крупные (диаметром около 0,8 мм) располагаются на боковых лопастях. Остальные значительно меньше (до 0,5 мм), причем их размер заметно уменьшается к переднему краю кранидия. Всего на глабели около 50 бугорков. На задней части глабели их расположение по системе Р. Триппа следующее: I-1; II-1, 2; iii-0; III-1,2* , 3; iv-1 (рис. 3). Ложное предглабельное поле несет 10-12 бугорков, из них крайние крупные, а срединные очень мелкие. Скульптура неподвижной щеки четкая около спинной борозды. Для пальпебрального поля характерны три бугорка, тесно расположенные между глазной крышкой и спинной бороздой - один крупный спереди и два поменьше на уровне заднего края глаза. На подвижной щеке скульптура выражена в основном окружающим глаз венком бугорков (до 0,5 мм), несколько удаленных от его основания. Вне венка, а также на передней части боковой каймы просматриваются низкие нечеткие бугорки. Псевдоглабельное поле покрыто такими же бугорками, как и в венке. Задняя краевая кайма без бугорков. Поры на бугорках кранидия, по имеющемуся материалу, не прослеживаются. 


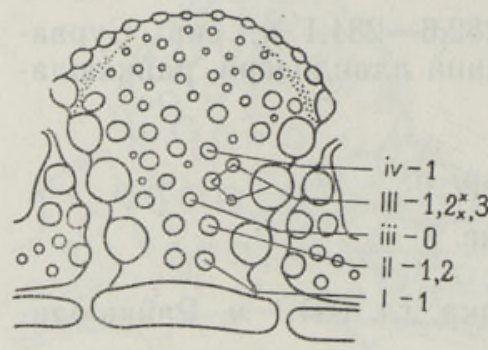

Рис. 3. Расположение бугорков на глабели Encrinurus abyssalis sp. n.
Туловище не найдено.

Пигидий широкий (ширина в $1,5-1,75$ раза больше его длины), с широким закругленным концом. Рахис составляег около 0,35 ширины всего пигидия и состоит из 15-16 колец. За вторым кольцом проходит почти гладкий осевой пояс. Спинные борозды умеренной глубины, слегка выгнутые. На плевральном поле 8 пар ребер, причем седьмая пара, сливаясь, образует конец пигидия, а восьмая, в зачаточном виде, лежит между ними. На рахисе осевые бугорки (диаметром около 0,3 мм) начинаются от второго и третьего колец, обычно повторяясь через каждые три. Кроме того, прослеживаются ряды мелких бугорков (диаметром около 0,1 мм) вдоль колец и по одному бугорку на проксимальных концах плевральных ребер.

Ср а внение. Изученный вид отличается от остальных прибалтийских энкринурид более близким расположением глаз к глабели, характерным для американского вида Fragiscutum glebalis (Campbell, 1967). E. abyssalis сходен с последним видом также по общему строению гипостомы и пигидия. Отличается от него значительно бо́льшим количеством бугорков разных размеров на глабели, а также их расположением.

Р асп р ост р а н ен и е. Скв. Колка, 602,6-604,3 м. Средний лландовери, райккюлаский горизонт.

\section{Encrinurus triangulus sp. n.} табл. II, фиг. $5-14$; рис. 4

Голотип. Неполный кранидий, $\operatorname{Tr} 1976$ a. Скв. Охесааре, 350,0 м. Адавереский горизонт, верхний лландовери.

М а те ри ал. 11 кранидиев, 10 подвижных щек, 3 гипостомы, 20 пигидиев.

Д и агно 3. Глабель несет около 30 бугорков, ложное предглабельное поле - 8. На пальпебральном поле два крупных эллиптических бугорка. Щечные углы заостренные. У гипостомы передний конец срединного тела вытянут за передний ее край. Пигидий треугольный, с заостренным в виде короткого шипа задним концом. Ширина пигидия немного больше его длины. Рахис составляет 0,3 ширины пигидия, состоит из 15 колец.

Опи с ани е. Слабо выпуклый кранидий с закругленным, слегка заостренным передним краем. Ширина кранидия вдвое больше его длины. Длина глабели в 1,2 раза больше ее ширины.

Базальные лопасти выражены слабо. Боковые лопасти развиты в виде крупных, слегка вытянутых к спинным бороздам бугорков. Боковые борозды не просматриваются. Предглабельная борозда широкая, особенно выделяется по бокам.

Спинные борозды широкие и глубокие, полого вогнутые. Ширина (тр.) затылочного кольца равна наибольшей ширине глабели. Щечные углы заостренные. Подвижные щеки характеризуются узкой краевой бороздой и относительно широкой, равномерной краевой каймой.

Передние ветви лицевых швов соединяются под углом около $130^{\circ}$. Относительно большие глаза расположены недалеко от глабели. 
В изученном материале имеются лишь гипостомы без задних частей. Срединное тело гипостомы выпуклое, со слабо выраженной передней лопастью. Передний ее конец остроугольно вытянут за передний край гипостомы. Макулы в виде овальных возвышений располагаются у заднебоковой борозды.

Скульптура на глабели образована четкими, относительно равномерными бугорками, количество которых у изученного материала колеблется от 26 до 33. Наиболее крупные, слегка вытяну-

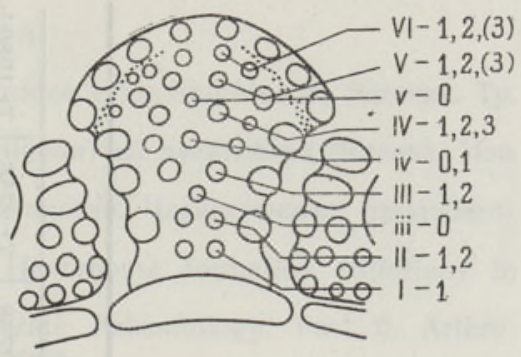

Рис. 4. Расположение бугорков на глабели Encrinurus triangulus sp. n. тые к спинным бороздам бугорки (диаметром до 1 мм) находятся на боковых лопастях. Остальные бугорки глабели немного меньше (до 0,8 мм), причем они не уменьшаются к передней части глабели. Расположение бугорков на глабели по системе Р. Триппа следующее: I-1; II-1, 2; iii-0; III-1, 2; iv-0, 1; $\mathrm{IV}-1,2,(3) ; \mathrm{V}-0 ; \mathrm{V}-1,2,(3) ; \mathrm{VI}-1,2,(3)$ (рис. 4). Ложное предглабельное поле несет обычно 8 бугорков, по величине аналогичных таковым на глабели. На псевдоглабельном поле около 15 низких бугорков. Непо . движные щеки покрыты четкими бугорками около спинной борозды. Два наиболее крупных (до 1,5 мм) эллиптических бугорка расположены между передней частью глазной крышки и спинной бороздой; два округлых, поменьше размерами, - на задней части пальпебрального поля. На подвижной щеке вблизи основания глаза имеется венок нечетких бугорков, за пределами которого находятся округленные или слегка удлиненные углубления (диаметром около 0,1 мм). На передней части боковой каймы иногда встречаются очень низкие бугорки.

Туловище не найдено.

Пигидий треугольного очертания со слабо вогнутыми боковыми краями и заостренным, загнутым кверху задним концом, имеющим вид короткого шипа. Ширина пигидия немного (в 1,2 раза) больше его длины. Рахис составляет 0,3 ширины всего пигидия и состоит из 15 колец. За вторым или третьим кольцами проходит неширокий осевой пояс, более четко выраженный в задней части рахиса. Спинные борозды низкие, особенно в задней части пигидия, дугообразно выгнутые. Плевральное поле имеет 7 пар ребер, разделенных относительно узкими межплевральными бороздами. Пострахиальная часть длиннее задних ребер, в передней части просматривается удлиненное углубление. Дублюра узкая. Скульптура на пигидии образована небольшими осевыми бугорками, которые начинаются от первого или второго кольца и повторяются через каждые три. Остальная поверхность гладкая, значительная зернистость выражена лишь на передней части дублюры.

С равнение. Данный вид относится к группе E. punctatus, для которой характерны небольшое количество бугорков на глабели и заостренный конец пигидия. Четко отличается от E. punctatus небольшим количеством рахиальных колец пигидия, слабой скульптурой щечного поля и другими признаками.

Р а сп р ост р а н е и е. Скв. Oхесааре, $349,0-352,1$ м; скв. Каугатума, 247,9-257,4 м; скв. Рухну, 457,6-462,2 $\mu$; скв. Колка, 571,5 $м$. Верхний лландовери, адавереский горизонт. 


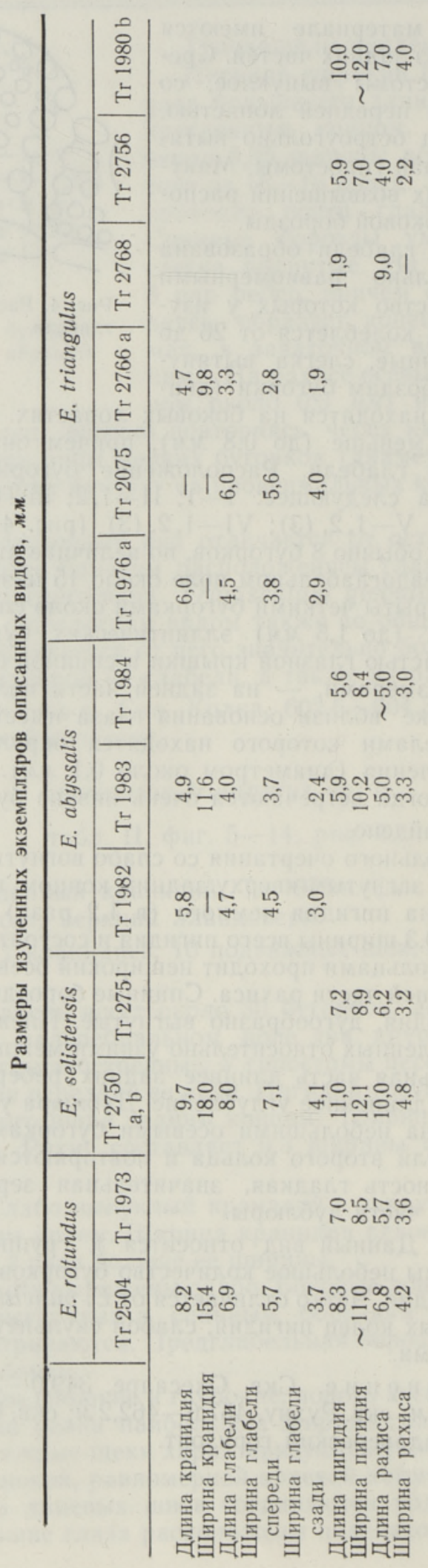




\section{Л ИТЕРА Т У РА}

М янни ль Р. М. 1958. Трилобиты семейств Cheiruridae и Encrinuridae из Эстонии. Тр. Ин-та геол. АН ЭССР, III.

М янн н ль Р. 1968. Encrinurus schmidti sp. n. (Trilobita) из лландовери Эстонии. Изв. АН ЭССР, Хим. Геол,, 17, № 3.

Ч ерн ш в а Н. Е. (ред.). 1960. Основы палеонтологин. Членистоногие, трилобитообразные и ракообразные. М.

Campbell K. S. W. 4967. Trilobites of the Henryhouse formation (Silurian) in Oklahoma. Geol. Survey, Bull., 115.

Moore R. C. (ed.) 1959. Treatise on Invertebrate Paleontology. Part 0. Arthropoda I. Geol. Soc. Am. and Univ. Kansas Press.

Reed F. R. C. 1928. Notes on the Family Encrinuridae. Geol. Mag., 65.

Rosenstein E. 1941. Die Encrinurus-Arten des estländischen Silurs. Publ. Geol. Inst. Univ. Tartu, Nr. 62.

$\mathrm{Schmidt}$ Fr. 1881. Revision der ostbaltischen silurischen Trilobiten. I. Mém. Acad. Sci. St.-Petersb., sér. 7, 30, Nr. 1.

Schrank E. 1972. Proetacea, Encrinuridae und Phacopina (Trilobita) aus silurischen Geschieben. Beiheft Zeitschr. Geologie, 76.

Te m p le J. T. 1956. Notes on the Cheiruracea and Phacopacea. Geol. Mag., 93, No. 5.

Trip P R. P. 1957. The trilobite Encrinurus multisegmentatus (Portlock) and allied Middle and Upper Ordovician species. Palaeontology, 1, No. 1.

Tripp R. P. 1962. The Silurian trilobite Encrinurus punctatus (Wahlenberg) and allied species. Palaeontology, 5, No. 3 .

Whittard W. F. 1938. The Upper Valentian Trilobite Fauna of Shropshire. Annals and Mag. Natur. History, ser. II, 1, London.

Whittington H. B., Cam pbel1 K. S. W. 1967. Silicified Silurian Trilobites from Maine. Bull. Mus. Comp. Zool., 135, No. 9.

Ннститут геологии

Академии наук Эстонской ССР
Поступила в редакцию 1/III 1976

\section{Reet MANNIL}

\section{BALTIKUMI LÄNDOUVERI UUSI ENKRINURIIDE (TRILOBITA)}

Baltikumi siluri senituntud enkrinuriidid pärinevad avamusalalt. Käesolevas kirjeldatakse Lõuna-Eesti ja Lääne-Läti puursüdamike pōhjal nelja uut liiki, mis pärinevad suhteliselt sügavaveelistest setetest.

Reet MANNIL

\section{SOME NEW LLANDOVERIAN ENCRINURID TRILOBITES OF THE EAST BALTIC AREA}

The family Encrinuridae is the richest in species among the Early Silurian trilobites of the East Baltic area. All the species known hereto come from the outcrop area. The present article deseribes four new species coming from the subsurface of southern Estonia and western Latvia.

\section{Encrinurus rotundus sp. $\mathrm{n}$.}

Pl. I, Figs 1, 2; Text-fig. 1

Glabella convex, with about 70 tubercles. On false preglabellar field 12 small tubercles. Genal spines missing. Central body of hypostome strongly convex, with median lobe slightly projecting but not covering anterior furrow. Pygidium rounded, its width exceeding length. Axis broad ( 0,4 widths of pygidium), transversely arched and composed of 15 rings. Postaxial ridge reaches the posterior margin of pygidium. Borings of Laeva $(121.2-125.5 \mathrm{~m})$, Survaküla $(190.5 \mathrm{~m})$, Otepää $(120.7 \mathrm{~m})$ and Häädemeeste $(408.8 \mathrm{~m})$. Lower Llandoverian, Juuru Stage $\left(\mathrm{G}_{1-2}\right)$. 
Encrinurus selistensis sp. $\mathrm{n}$.

Pl. II, Figs 1-4; Text-fig. 2

Glabella moderately convex, with 54 tubercles. On false preglabellar field 12 , on palpebral area 5-6 tubercles. Genal angles without spines. Median lobe of central body of the hypostome projects slightly forward, but does not reach the anterior border. Pygidium triangular, approximately as long as wide. Axis composed of 20-22 rings. Postaxial ridge does not extend to posterior margin of pygidium.

Borings of Seliste $(282.6-284.1 \mathrm{~m})$, Survaküla $(150.6 \mathrm{~m})$, Ristiküla $(233.4 \mathrm{~m})$. Middle Llandoverian, Raikküla Stage $\left(\mathrm{G}_{3}\right)$.

\section{Encrinurus abyssalis sp. $\mathrm{n}$.}

Pl. I, Figs 5-10; Text-fig. 3

Cranidium broadly rounded anteriorly. Approximately 30 tubercles on glabella (including large lateral tubercles), 10-12 small tubercles on false preglabellar field and 3 tubercles on palpebral area. Fixed cheeks with small spines. Palpebral lobes long, their anterior extremities close to axial furrows. Pygidium wide, with rounded posterior border. Axis arched transversely and composed of 15-16 rings. On pleural region 8 pairs of ribs, the last of them strongly arched and does not extend to posterior margin of pygidium.

Kolka boring $(602.6-604.3 \mathrm{~m})$. Middle Llandoverian, Raikküla Stage $\left(\mathrm{G}_{3}\right)$.

Encrinurus triangulus sp. $\mathrm{n}$.

Pl. II, Figs 5-14; Text-fig. 4

Glabella strongly and evenly tuberculate, approximately with 30 tubercles. On false preglabellar field 8 tubercles. Palpebral area characterized by two big elongated tubercles anteriorly and two rounded tubercles posteriorly. Genal angles pointed. The sharpened anterior part of central body of the hypostome projects forward from anterior border. Pygidium triangular, with short upturned mucro. Width of pygidium exceeding length. Axis about 0.3 widths of pygidium, composed of 15 rings.

Borings of Ohesaare $(349.0-352.1 \mathrm{~m})$, Kaugatuma $(247.9-257.4 \mathrm{~m})$, Ruhnu $(457.6-462.2 \mathrm{~m})$, Kolka $(571.5 \mathrm{~m})$. Upper Llandoverian, Adavere Stage $(\mathrm{H})$. 